\title{
Neki problemi pri prevođenju moderne poezije promatrani kroz teoriju konceptualne integracije
}

Straußeneimond

aber ich finde nichts mehr

nichts mehr an Buchstaben im Wort

mache so ähnlich

wie Luftgang ohne Seil

es fällt nichts mehr

aber nichts ist eben auch

Zaungrenze

und Leben

Mittelstelzengang

der Strauß legt seine Eier in den Himmel

fast Massenproduktion

kugelrunde Stunden

mit Haut auf wirren Überzug

Hände greifen leer

wenn nicht du

aber das kann nicht - 
Angsttauchen mit Höhengang

und die Hand als Schale

wer fängt, - verliert!

Mjesec od nojevog jajeta

ali nema ničeg više

ničeg više u slovima riječi

činim slično

kao hod po zraku bez konopca

ništa više ne pada

ali i ništa jest

granica od ograde

i život

sredinom na štulama

noj liježe svoja jaja u nebo

gotovo masovna proizvodnja

sati okrugli poput lopte

s kožom na neurednoj presvlaci

ruke posežu u prazno

ako nisi ti

ali to ne može -

uron $\mathrm{u}$ strah s letom u visine

i ruka poput ljuske

tko ulovi, - izgubi! 


\section{Uvod}

Prevođenje poezije oduvijek se smatralo osobitom temom unutar ionako složenog područja književnog prevođenja. Budući da poezija predstavlja književni oblik u kojem su sadržaj i forma nerazdvojno povezani ${ }^{[1]}$ jasno je zašto ona predstavlja najzahtjevniji oblik prevoditeljske aktivnosti. Problematičnu točku pri prevođenju poezije predstavlja činjenica da ona daje izrazito "zgusnutu" i kompaktnu formu te da jezik poezije uglavnom počiva na konotacijama, a ne na denotacijama. Noviji pristupi prevođenju prepoznaju da su nekadašnja protivljenja prevođenju poezije, to jest isticanja njezine neprevodivosti, zapravo bila usmjerena na nemogućnost potpunog prenošenja svih aspekata izvornog poetskog djela u ciljni jezik i njegovu kulturu i tradiciju ${ }^{2]}$ (neprevodivost poezije isticali su, primjerice, T. S. Eliott: “[poezija je] stalni podsjetnik na sve ono što se može reći samo na jednom jeziku ${ }^{\lceil 3]}$, Roman Jakobson: "poezija je po definiciji neprevodiva ${ }^{[4]}$ ili Nabokov: "pjesma ne može biti prevedena, reproducirana ni iznova oblikovana na ciljnom jeziku"55] (svi navedeni citati te citati koji slijede u vlastitom su prijevodu, osim ako nije drugačije naznačeno). U 20. stoljeću oformio se, između ostalih, pristup da je zadatak prevoditelja prijevodom oponašati izvorno lirsko djelo, a uz to što prijevod treba preslikavati original, on također treba zadržati i njegovu poetsku vrijednost te u ciljnom jeziku funkcionirati kao samostalna poetska forma (bez glosa, komentara ili fusnota). Budući da je svaka pjesma priča za sebe, svaki je prevoditelj pri definiranju prioriteta (zvučnost? semantika? rima? ritam?) prepušten samom sebi i konstantno se suočava s izborima (Jones (citat u Connolly 174) prevođenje poezije naziva "umjetnošću kompromisa"). W. S. Merwin opisuje svoj pristup prevođenju poezije na sljedeći način: "Znate, i dalje vjerujem da ne znam kako se prevodi i da to nitko ne zna. To je nemoguć, ali nužan proces, ne postoji savršen način da se on izvede i velik njegov dio mora se oblikovati u hodu za svaku pojedinačnu pjesmu. ${ }^{[6]}$

\section{Poezija i prevođenje}

\subsection{Konceptualna integracija}


Općenito možemo reći da je poezija na svoj način izdvojena iz konteksta i odvojena od konkretnog okruženja koje inače pronalazimo kod proznih tekstova, što čitatelju (i prevoditelju) otežava izgradnju vlastite mentalne predodžbe njezina sadržaja i konteksta u koji se taj sadržaj uklapa. T. S. Eliott, primjerice, svoj je pristup prevođenju moderne poezije zanimljivo karakterizirao kao “sretan spoj duha originala i uma prevoditelja” ${ }^{[7]}$ (citat u Naaijkens 1671), dok Felstiner u svojim bilješkama sastavljenima pri prevođenju pjesama P. Nerude ističe "manjak kohezivne teksture" što vodi ka intuitivnim odlučivanju jer je vodstvo izvornika slabo (citat u Naaijkens 1672).

Pri pokušaju objašnjavanja pristupa prevođenju, a u ovom slučaju konkretno prevođenju moderne poezije, možemo se pozvati na teoriju konceptualne integracije koju su Fauconnier i Turner definirali kao temeljnu operaciju koja se odvija tijekom misaonih procesa, a proizlazi iz teorije mentalnih prostora. Mentalni prostori su "konceptualni paketi konstruirani dok mislimo i govorimo, s ciljem lokalnog razumijevanja i djelovanja. ${ }^{[8]}$. Oni nastaju paralelno s procesom komunikacije i sadrže elemente koji su međusobno povezani kroz različite odnose. Mentalni prostori pri izgradnji koriste opća i specifična znanja, povezani su sa shematiziranim iskustvima i znanjima čija aktivacija upotpunjuje strukturu mentalnih prostora. Teorija konceptualne integracije u prototipnim slučajevima uključuje sljedeće elemente: dva ulazna prostora, generički prostor i projekcijski prostor. Postoje i slučajevi kompliciranijih konceptualnih mreža koje uključuju više od dva ulazna prostora, no njima se u ovom radu nećemo baviti. Ulazni prostori sadrže ulazne informacije i elemente koje te informacije donose sa sobom. Generički prostor sadrži s ulaznim prostorima zajedničke elemente i omogućuje njihovo povezivanje u projekcijski prostor. U projekcijskom prostoru nalaze se elementi iz obaju ulaznih prostora, povezani kroz manje ili više individualnu značenjsku interpretaciju izraza i sadržaja. Ova interpretacija uvjetovana je različitim utjecajima: kontekstom, iskustvom i znanjem pojedinca, nesvjesnim upotpunjavanjem konceptualne strukture.

\subsection{Konceptualna integracija pri prevođenju}

Kada govorimo o teoriji konceptualne integracije i njezinoj povezanosti s procesom prevođenja, možemo spomenuti problem interpretacije sadržaja, to jest izgradnje predodžbe izvorne informacije te integraciju tog sadržaja i jezične formulacije u ciljnom jeziku. Nekolicina autora konkretnije se bavila analizom procesa prevođenja kroz teoriju konceptualne integracije, Mandelblit 
(193), primjerice, naglašava da se proces prevođenja sastoji iz dvostruke konceptualne integracije, to jest iz deintegracije i integracije. Kroz deintegraciju prevoditelj dolazi do konceptualne strukture oblikovane u originalu, on najprije mora interpretirati izvorni sadržaj, "otpakirati" informaciju i na temelju jezične formulacije rekonstruirati proces povezivanja konceptualnog i jezičnog sadržaja. Nakon toga kroz proces integracije prevoditelj tu konceptualnu strukturu kombinira s jezičnim oblikom u ciljnom jeziku i tako stvara novu kombinaciju, prikladnu ciljnom jeziku i ciljnoj kulturi. Ovaj je proces samo umjetno razdvojen na dvije faze, on se u realnom vremenu zapravo vrlo vjerojatno odvija (gotovo) istovremeno.

U idealnom slučaju rezultat ovog postupka vodi preko ciljne jezične natrag do izvorne konceptualne strukture koju je oblikovao autor. Uspješnim prijevodom prema Mandelblit i Wang Bin smatra se onaj koji čitatelja u ciljnom jeziku svojim izrazom navodi na izgradnju konceptualnog sadržaja i mentalne predodžbe slične onoj koju na temelju izvorne formulacije izgrađuje čitatelj u izvornom jeziku. Problem prema Wang Bin (1) pri tome predstavlja to što je proces integracije konceptualnog sadržaja znatno složeniji i detaljniji od mogućnosti koje nudi jezični izraz te tako formulacija u izvornom jeziku daje samo naslutiti koja je polazišna točka za rekonstrukciju konceptualnog sadržaja, to jest odnosa između koncepta i jezičnog izraza, mnogo prostora ostaje za vlastitu interpretaciju i eventualne nesporazume (problem znatno veći i učestaliji nego u komunikaciji na istom jeziku kod koje također može doći do nesporazuma).

Kao što je opisano, teorija konceptualne integracije polazi od toga da izvornik svojom jezičnom formulacijom čitatelja vodi k oblikovanju mentalne predodžbe o konceptualnom sadržaju izraženom u originalnom djelu. U slučaju poezije ovaj je aspekt osobito problematičan, ponajviše iz gore navedene izdvojenosti pjesme iz većeg konteksta. Kontekstualizaciji pripomažu informacije o autoru, o tome u kojem je razdoblju bio aktivan, što je proživljavao kroz svoj život te kakvim se pitanjima bavio, kakav mu je opus, no ni ovo nije garancija da će pročitana pjesma biti i razumljivija jer ona nudi pojedinačne slike koje čitatelj/prevoditelj najprije treba pojedinačno oblikovati, a zatim pokušati povezati u zatvoren krug.

Ako polazimo od toga da autor spajanjem izraza i predodžbe stvara originalan spoj koji prevoditelj mora rastaviti na sastavnice (razdvojiti izraz od predodžbe) i zatim iznova spojiti/stvoriti u ciljnom jeziku, tada pri prevođenju poezije prevoditelj mora izgraditi određenu vrstu imaginarnog svijeta 
izvorne pjesme u kojem situacije i spojevi koji u realnom svijetu možda nemaju smisla u pjesmi sasvim normalno funkcioniraju i daju smislenu sliku. Kako bi se ostvario ovaj cilj, potreban je intenzivan rad na tekstu, kako na izvorniku tako i na prijevodu. Uza sve navedeno postavlja se pitanje je li izraz uopće moguće razdvojiti od predodžbe, s obzirom na to da smo već spomenuli kako je veza između forme i sadržaja u poeziji vrlo čvrsta. Odgovor na ovo pitanje svakako bi bio da se izraz, barem djelomično, ne samo može nego i mora razdvojiti od konceptualnog sadržaja jer inače nikada ne bismo mogli na drugom jeziku reproducirati književno/poetsko djelo i oblikovati njegov prijevod, nego bismo ga mogli samo percipirati u njegovu izvornom obliku.

\section{Analiza prijevoda}

\subsection{Izvor i postupak}

Konačna verzija pjesme i njezine prijevodne varijante koje tematiziramo u ovom radu nastale su u sklopu priprema prijevoda za čitanje poezije autora Hermanna Niklasa i Marie Seisenbach koji su u ožujku 2010. godine u Osijeku predstavili svoju zbirku poezije "Konfrontationen" u sklopu manifestacije Dani austrijske kulture. Pjesme prema izjavama autora uglavnom tematiziraju ljubav, međuljudske odnose i refleksiju, opisuju manje ili više apstraktne događaje koji izazivaju određene reakcije, to jest emocije u autorima. Prijevodi svih pjesama nastali su suradnjom studenata diplomskog studija njemačkog jezika prevoditeljskog usmjerenja u Osijeku kao glavnih prevoditelja, asistentice na kolegiju književnog prevođenja kao savjetnice te samih autora poezije koji su proces podupirali svojim komentarima i odgovorima na pitanja koja su se eventualno pojavila. Prijevod pjesme "Straußeneimond" na hrvatski jezik izradila je studentica Sanja Matković.

Proces prevođenja odvijao se na sljedeći način: studentica je najprije samostalno izradila prvu varijantu prijevoda, pri tome su joj kao pomoć poslužila opća pitanja koja je savjetnica sastavila za sve studente/prevoditelje. Pitanja su bila usmjerena na mentalne slike koje pjesma izgrađuje te usmjeravala $\mathrm{k}$ interpretaciji pjesme i oblikovanju pojedinačnih slika unutar pjesme u zatvorenu cjelinu. Konačne odluke donosio je student prevoditelj. Prva verzija prijevoda i odgovori na pitanja služili su kao osnova za raspravu o različitim aspektima pjesme i (ako je potrebno) za izradu pitanja za autore. Pomoću autorovih odgovora sastavljala se nova verzija koja je u dogovoru sa 
savjetnicom prolazila konačnu obradu i dobila svoj konačni oblik. Prijevodi su nastali u proljeće 2010. godine te bi, kao i svaki prijevod, danas ponovno bili podložni korekciji i reinterpretaciji (ne smijemo zaboraviti da su ovo za studente bili prvi bliski susreti s modernom poezijom na njemačkom jeziku i njezinim prevođenjem, stoga ne možemo očekivati prijevod bez pogrešaka), no pri analizi nećemo mijenjati prijevod, nego ćemo kao konačnu verziju koristiti onu nastalu u samom procesu uz eventualne prijedloge za poneku korekturu.

\subsection{Autoričini komentari}

Obraćanje autorici s nekoliko osnovnih pitanja bila je izvorna ideja i iako su odgovori u određenoj mjeri bili od pomoći, ipak ostaje Sokratova tvrdnja iz Platonove "Apologije" koju prenosi Connolly (173), kako su sami čitatelji često bolje informirani od autora te kako značenje pjesme ne počiva u autoru, nego u samoj pjesmi i načinu na koji je čitatelj interpretira. Ovako je autorica pjesme objasnila svoj opći stvaralački pristup pjesmama: "Pjesme su za mene polja kojima prolazim. Na takvim poljima raste različito cvijeće (riječi), ja priđem nekoj riječi (cvijetu) i iskusim što taj cvijet sa mnom čini, mogu ga čupkati, mirisati, iščupati, mogu ga zanemariti, no taj cvijet (riječ) mi sasvim jasno nešto govori. Naravno, odvojeno od uobičajene riječi (op. prev. jezične formulacije). Jasno je da polja imaju i svoj kraj i kada prijeđemo njegove granice, tada prelazimo i besmislenost i očaj koji nastaju na prvi pogled. Možda se izvan zadanog polja nalazi smisao za svakoga."

Opće pojašnjenje pjesme koju tematiziramo u ovom radu, kako ga je ponudila sama autorica, sljedeće je: "Pjesma se bavi imaginarnim Mjesecom koji predstavlja iluziju koja je postala stvarnost - osoba je zaljubljena i prošlo je prvo razdoblje. Sada predstoji zadatak kretanja zajedničkim putem, stvaranja zajedničkog jezika (ali nema ničeg više u riječima...). Istovremeno je vrlo pozitivno kada u starim riječima više nema ničega što bi opisivalo nešto novo jer stječu se nova iskustva - to označava ova rečenica. "Ovo pojašnjenje trebalo je pomoći studentici pri stvaranju općeg konteksta pjesme i uklapanju pojedinačnih slika u zajednički okvir.

Dodatna pojašnjenja pojedinačnih riječi bila su:

Luftgang ohne Seil (kao hod po zraku bez konopca): bez konopca znači rizik (čovjek riskira kada se nekome povjeri - to nema nužno samo pozitivno značenje, ako čovjek osjeća strah od 
povrede), a hod po zraku (je nešto lijepo, odjednom je hod tako lak, život djeluje ružičasto (zaljubljeno) i sve to bez konopca (ako nešto krene po zlu, tada pri padu nema konopca).

Zaungrenze (granica od ograde): svaka ograda ograničava komad zemlje (svaki čovjek ograničava svoje tijelo, svoj duh) i tada dodatno granica te granice/ograde (dvostruka granica koja nije nužna, ali je, eto, izgrađena iskustvom).

Mittelstelzengang (sredinom na štulama): put kroz sredinu, opet nije nužno osobito prizemljen, dakle pomalo lebdeći, ali dobiva oslonac preko štula.

\subsection{Prijevodne verzije}

Pjesma "Mjesec od nojevog jajeta" odabrana je jer nudi niz elemenata zanimljivih za analizu s translatološkog i kognitivnog stajališta. Pri analizi pjesme osobito nam je bitna atmosfera koju izgrađuje književno djelo, a poezija to obilježje još više ističe. Na prvu ruku pjesma podsjeća na umjetničke slike Salvadora Dalija - sintaksa koja bi elemente povezala u smislenu cjelinu vrlo je oskudna, ako i postoji (npr. wenn nicht du/aber das kann nicht), ona ne donosi pojašnjenje, nego svojom nepotpunošću čak dodatno zbunjuje; spominju se nojeva jaja (Straußenei), štule (Stelzen, Mittelstelzengang), dijelovi tijela (Haut, Hand), vrijeme, riječi, visina, dubina - elementi ne daju koherentnu sliku, što zapravo predstavlja najveći problem. Budući da su pjesme pisane u slobodnom stihu, nije se pojavio problem ekvivalentnosti vrste stiha, rime ili broja slogova, cjelokupna analiza fokusirala se na semantičku stranu pjesama koju smo smatrali najvažnijim elementom. Ako polazimo od kognitivnog pristupa prevođenju, gdje bi nam izvornik trebao ponuditi minimum informacija kako bi se stvorila osnova koju bi prevoditelj zatim mogao upotpuniti svojim već postojećim znanjem i asocijacijama, tada nam je jasno zašto je ova pjesma (kao i ostale iz zbirke) problematična: elementi na prvi pogled ne podupiru jedan drugoga, nije moguće bez poteškoća povezati nojeva jaja, konopac, riječi i štule u smislenu cjelinu, pjesma ne nudi priču i tijek, nego pojedinačne isječke iz iste priče među kojima postoje praznine. Dio problema čini činjenica da pjesme posjeduju samo naznake sintaktičke strukture, zbog čega je teško odrediti gdje misao završava, to jest veže li se sljedeći stih na prethodni te time i na prethodnu misao ili na sljedeći stih i na misao koja tek slijedi. S druge strane, problematična je snažna konotativnost riječi 
jer, budući da ne dijelimo svi iste konotacije kada su u pitanju određene riječi, studentica mora pokušati pronaći i shvatiti konotativnu stranu izraza upotrijebljenog u pjesmi.

U nastavku su prikazane tri verzije pjesme "Mjesec od nojevog jajeta": a) predstavlja prvu verziju nastalu nakon zajedničke interpretacije sadržaja, b) međukorak prema konačnoj verziji, a c) konačnu verziju navedenu na početku ovog rada. Podvučeni elementi u prijevodnim verzijama oni su koji su se promijenili u odnosu na prethodnu verziju, uglavnom na sugestiju savjetnice (u slučajevima doslovnog prevođenja, pogrešno shvaćene formulacije izvornika ili na neki način nedovoljno poetične formulacije u prijevodu).

\subsubsection{Verzija a)}

Ova verzija predstavlja prvi korak nakon deintegracije sadržaja izvornika i stoga najjače pokazuje pogreške koje je prevoditeljica napravila boreći se s nejasnoćama te s nastojanjem stilski što uglađenijeg izražavanja na ciljnom jeziku. Problemi koji se javljaju ukazuju na činjenicu da imaginarni svijet izvornika za prevoditeljicu u početku velikim dijelom ostaje apstrakcija, ona zapinje pri sastavljanju neke vrste koherentne nekoherentnosti, to jest smislene besmislene slike, pjesma ostaje izvan nje i ona je ne izgrađuje iznova kao svoju interpretaciju, već je samo prenosi onakvu kakvom joj se čini u izvorniku, a time u ciljnom jeziku stvara i poneku nezgrapnost koje u originalu nema.

Straußeneimond

aber ich finde nichts mehr

nichts mehr an Buchstaben im Wort

mache so ähnlich

wie Luftgang ohne Seil

es fällt nichts mehr

aber nichts ist eben auch

Zaungrenze

und Leben 


\section{Mittelstelzengang}

der Strauß legt seine Eier in den Himmel

fast Massenproduktion

kugelrunde Stunden

mit Haut auf wirren Überzug

Hände greifen leer

wenn nicht du

aber das kann nicht -

Angsttauchen mit Höhengang

und die Hand als Schale

wer fängt, - verliert!

a) Mjesec od nojevog jajeta

ali ne pronalazim ništa više

ništa više u slovima riječi

činim tako slično

kao protok zraka bez konopca

ništa više ne pada

ali ništa nije također

granica od ograde

i život

srednji put na štulama

noj liježe svoja jaja u nebo

gotovo masovna proizvodnja 
sati okrugli poput lopte

s kožom na neurednoj presvlaci

ruke posežu u prazno

ako ne ti

ali to ne može -

uranjanje u strah s putom uvis / zaron sa strahom od visine???

i ruka poput ljuske

tko lovi, - izgubi!

Formulacije koje prepoznajemo kao doslovni prijevod s njemačkog jezika (wie Luftgang ohne Seil kao protok zraka bez konopca, Mittelstelzengang - srednji put na štulama, aber nichts ist eben auch - ali ništa nije također, mache so ähnlich - činim tako slično) ukazuju na točke na kojima je bio potreban dodatan rad jer pokazuju plitku razinu razumijevanja i nemogućnost stvaranja koherentne slike. U nekim slučajevima to je sasvim logično jer riječi poput Luftgang i Mittelstelzengang jedinstvene su novotvorenice te im značenje i nije moguće ad hoc definirati (upravo su te riječi zahtijevale dodatna objašnjenja autora (poglavlje 3.2.)). Drugi su, pak, problemi proizašli iz nedovoljnog obraćanja pažnje na činjenicu da ne predstavlja svaki stih jedinicu za sebe, već da oni tvore cjeline i time nam olakšavaju razumijevanje naizgled nedorečenog materijala i izbor odgovarajuće ciljne formulacije. Mjesto koje najjednoznačnije ukazuje na nerazumijevanje i nemogućnost oblikovanja mentalne predodžbe jest prvi prijedlog prijevoda stiha Angsttauchen mit Höhengang (uranjanje u strah s putom uvis/zaron sa strahom od visine???) - studentica nudi dvije verzije označene upitnicima što nam govori da nije uspjela ugraditi stih u svoju interpretaciju pjesme, da mu nije pronašla smisleno mjesto. Problematičnost njemačkih složenica koje često nemaju jednoznačno definirane odnose među elementima i ovdje dolaze do izražaja: nije jasno koji je odnos između riječi Angst i Tauchen te Höhe i Gang, usto nije jasno ni koje od više značenja pojedine riječi u konkrenom kontekstu pjesme treba doći do izražaja. Uz navedene probleme, pri interpretaciji pjesme otkrivena je i igra riječi Angsttauchen - Höhengang u odnosu na Höhenangst und Tauchgang (njem. strah od visine i ronjenje/zaron). Na spomen navedenog "otkrića" autorica 
pjesme reagira s oduševljenjem, no istovremeno i objašnjenjem kako igra riječi nije bila namjerna ("Nisam to tako mislila, no sad želim to tako misliti"). Navedena "pogrešna" interpretacija autorici se očito svidjela i ona je, čini se, u skladu s duhom pjesme, što je čini legitimnom i prihvatljivom iako to ne mijenja činjenicu da ona objektivno gledajući (vidljivo iz objašnjenja autorice) nije ono "što je autor pjesmom želio reći”. Budući da je autorica jasno rekla da navedena igra riječi nije namjerno korištena u pjesmi, prevoditeljica je svjesno odlučila ne inzistirati na sličnom stilskom izražavanju u prijevodu, osobito stoga što bi pronalaženje slične igre riječi uvelike otežalo izradu prijevoda. Jasno je da nerazumijevanje originala dovodi do problema pri oblikovanju predodžbe i njezinu izražavanju u ciljnom jeziku, no ponekad i izrazi koji su u izvorniku pojedinačno sami po sebi jasni u odabranoj kombinaciji ne daju jednoznačnu predodžbu, primjerice, sam naslov pjesme, Straußeneimond. Rasprava se razvila oko pitanja radi li se u ovom slučaju o Mjesecu koji je izgrađen od nakupine nojevih jaja ili se pak radi o punom Mjesecu koji izgleda kao jedno nojevo jaje (slično pričama ili poslovicama u kojima se Mjesec prikazuje kao veliki komad sira). Obje mentalne slike zadržavaju elemente iznesene u originalu (Mjesec, nebo, nojevo jaje), no razlika među njima je bitna i kao konačna odabrana je slika Mjeseca kao jednog velikog nojevog jajeta te time i verzija Mjesec od nojevog jajeta, a ne Mjesec od nojevih jaja (ovu verziju čini se da podupire i autoričino objašnjenje o imaginarnom Mjesecu koji je postao stvarnost (poglavlje 3.2.)).

\subsubsection{Verzija b)}

Usporedbom prijevodnih verzija a) i b) primjećujemo određene preinake. Stih aber ich finde nichts mehr/nichts mehr an Buchstaben im Wort prilagođen je izvornom značenju (nemogućnost pronalaženja riječi za opis novog iskustva - prema komentarima autorice), formulacija ne pronalazim ništa više zamijenjena je nešto stativnijom formom nema ničeg više kojom se nedostatak izriče kao činjenica nastala bez izravnog utjecaja lirskog ja, što je i prirodnije u odnosu na izraz ne pronalazim koji možemo promatrati kao interferenciju iz njemačkog jezika.

Pri formulaciji b) varijante ponašam se slično/kao da hodam po zraku bez konopca studentica je zapravo parafrazirala te sebi i čitatelju objasnila izvorni stih koji je i njoj samoj pri prijevodu predstavljao problem. Ova parafraza uvelike olakšava razumijevanje prvog dijela pjesme, no istovremeno predstavlja i prevelik zahvat u sam izraz i princip pjesme s obzirom da je upravo ta 
točka u originalu predstavljala nejasnoću, odnosno bila izražena vrlo stiliziranim jezikom (novotvorenicom). Spomenuti se stihovi mijenjaju i u verziji c).

Formulacija ali ništa nije također u verziji a) (prijevod stiha aber nichts ist eben auch) za početak ukazuje školski pristup izvornoj strukturi, njemački modalni izraz eben općenito je problematičan kada govorimo o prijevodu na hrvatski te je izostavljen, dok je izraz auch doslovno preveden s također - riječ koja se u hrvatskom jeziku ne može koristiti u negativnom kontekstu. Iz ovog razloga i još važnije stoga što ovakav prijevod nije sadržajno ekvivalentan originalu (doslovan prijevod bio bi ali ništa je ipak također) dolazi do promjene u varijanti b), a kasnije i u varijanti c).

a) Mjesec od nojevog jajeta

ali ne pronalazim ništa više

ništa više u slovima riječi

činim tako slično

kao protok zraka bez konopca

ništa više ne pada

ali ništa nije također

granica od ograde

i život

srednji put na štulama

noj liježe svoja jaja u nebo

gotovo masovna proizvodnja

sati okrugli poput lopte

s kožom na neurednoj presvlaci

ruke posežu u prazno

ako ne ti

ali to ne može - 
uranjanje u strah s putom uvis / zaron sa strahom od visine???

i ruka poput ljuske

tko lovi, - izgubi

b) Mjesec od nojevog jajeta

ali nema ničeg više

ničeg više u slovima riječi

ponašam se slično

kao da hodam po zraku bez konopca

ništa više ne pada

ali ništa je također

granica od ograde

i život

sredina na štulama

noj liježe svoja jaja u nebo

gotovo masovna proizvodnja

sati okrugli poput lopte

s kožom na neurednoj presvlaci

ruke posežu u prazno

ako nisi ti

ali to ne može -

uranjanje u strah s letom u visine

i ruka poput ljuske

tko ulovi, - izgubi! 
Izraz Mittelstelzengang studentica je u varijanti a) prevela kao srednji put na štulama, riječ Gang shvatila je, dakle, kao put, no ta riječ znači i kretanje, hod, a kako je originalna riječ novotvorenica nejasnog i novog značenja i za izvornog govornika, u varijanti b) odabrana je formulacija sredina na štulama - neutralnija i manje interpretativna.

Već spomenuta činjenica da slaba sintaksa ponekad otežava povezivanje stihova u cjeline, sa sobom, naravno, nosi i problematiku interpretacije i prijevoda takvih stihova. Takav slučaj primjećujemo u prijevodnim varijantama stiha wenn nicht du. Verzija a) ako ne ti izmijenjena je u verziju b) ako nisi ti, iako iz pjesme nije potpuno jasna veza između spomenutog stiha i ostatka. Kao logična nameće se interpretacija u kojoj se povezuju stihovi Hände greifen leer/wenn nicht du - ruke posežu u prazno ako tebe nema, no navedena verzija ponovno bi predstavljala izravnu interpretaciju pjesme, a ne njezin prijevod, stoga je prihvaćena verzija ako nisi ti koja asocira na značenje "ako nisi ti tu" ili jednostavno znači "ako nisi ti" u smislu postojanja voljene osobe.

Ranije spomenuto zanemarivanje smislene cjeline nauštrb pojedinačnog stiha vidljivo je u stihovima und die Hand als Schale/wer fängt, - verliert!: ova formulacija podsjeća na dječje igre u kojima dijete rukama hvata/lovi neki predmet (na to nas upućuje ruka poput ljuske - u tom položaju najlakše je rukama nešto uhvatiti), no uobičajen slijed događaja jest da onaj tko nešto ulovi/uhvati, zapravo pobijedi u igri, dok pjesma govori drugačije. Korekcije su izvedene na nesvršenom/svršenom obliku glagola loviti (tko lovi - tko ulovi), a moguća je i rasprava o tome je li bolja formulacija tko ulovi u odnosu na standardniju tko uhvati jer riječ loviti češća je u različitim dječjim igrama ("ulovi me, ulovi me”; igra lovice i sl.), dok njemačka riječ fangen pokriva značenje obiju verzija. Možemo reći da verzija b) pokazuje veću povezanost elemenata unutar cjeline, veći stupanj filtriranja pjesme kroz vlastito poimanje njezina sadržaja i atmosfere. Pri tome ne mislimo na objašnjavanje pjesme, već na oblikovanje prijevoda kao fotografije originala, ali kroz objektiv koji izvornoj situaciji, izvornom događaju ponešto mijenja nijanse ili ga prikazuje s drugačijeg stajališta. Verzija b) pokazuje dublju deintegraciju izvornog sadržaja te bolje upotpunjavanje informacije kroz vlastita iskustva i shematizirana znanja.

\subsubsection{Verzija c)}


Verzija c) logično je najzaokruženija od sve tri verzije: prijevod nam nudi jednak stupanj "konotacijske besmislenosti" kao i original, no sada se čini da se elementi bolje uklapaju jedan u drugi te pjesma bolje "teče" i djeluje zaokruženije. Određenim elementima iz verzije b) mijenja se jezična forma, čime se mijenja i mentalna predodžba koju izaziva upotrijebljeni izraz. Tako se, primjerice, ponašam se slično mijenja u činim slično (original mache so ähnlich), čime se stih manje ističe u odnosu na ostale te je time sličniji originalu koji također nije posebno naglašen.

b) Mjesec od nojevog jajeta

ali nema ničeg više

ničeg više u slovima riječi

ponašam se slično

kao da hodam po zraku bez konopca

ništa više ne pada

ali ništa je također

granica od ograde

i život

sredina na štulama

noj liježe svoja jaja u nebo

gotovo masovna proizvodnja

sati okrugli poput lopte

s kožom na neurednoj presvlaci

ruke posežu u prazno

ako nisi ti

ali to ne može -

uranjanje u strah s letom u visine 
i ruka poput ljuske

tko ulovi, - izgubi!

c) Mjesec od nojevog jajeta

ali nema ničeg više

ničeg više u slovima riječi

činim slično

kao hod po zraku bez konopca

ništa više ne pada

ali i ništa jest

granica od ograde

i život

sredinom na štulama

noj liježe svoja jaja u nebo

gotovo masovna proizvodnja

sati okrugli poput lopte

s kožom na neurednoj presvlaci

ruke posežu u prazno

ako nisi ti

ali to ne može -

uron u strah s letom u visine

i ruka poput ljuske

tko ulovi, - izgubi!

Dolazi do promjena iz verbalnih u formulacije s imenskim frazama, s obzirom da imenice donose semantiku (predmet, događaj kao cjelinu), no ne objašnjavaju slijed događaja ni sam događaj, već 
ostavljaju više nedorečenosti i time čitatelju otvaraju prostor za vlastito povezivanje i interpretaciju (kao što to čini i original): kao da hodam po zraku bez konopca mijenja se u kao hod po zraku bez konopca. Ovime čitatelju ne dajemo gramatičko lice (hodam), nego neutralnu izjavu koju on sam može popuniti informacijama koje nedostaju i oblikovati predodžbu (tko hoda, kakav je to hod i sl.). Uzrok promjeni formulacije sredina na štulama iz nominativa u instrumental sredinom na štulama ponovno leži u povezivanju slika i stihova: original glasi samo Mittelstelzengang - bez glagola, bez člana koji bi objasnio o kojem je padežu riječ, u prijevodu je odabrana formulacija sredinom na štulama koja neizravno instrumentalom ukazuje na kretanje, ne spominjući pritom, uz sredstvo (štule), način kretanja, put ni smjer. U ovom slučaju instrumental prijevodu dodaje značenjsku dimenziju koja nije izričito prisutna u originalu, no može se jasno izvesti iz autoričina objašnjenja riječi i teme pjesme: Mittelstelzengang je na neki način značenjski povezana s izrazom Luftgang ohne Seil - obje fraze odnose se na osjećaj lakoće koju zaljubljenost nosi uz istovremeno spominjanje rizika od razočaranja (bez konopca), odnosno pojedinačnih prizemljenih aspekata (štule kao pomoć pri hodu). Iz ovog razloga instrumental možemo promatrati kao suptilnu poveznicu među slikama u pjesmi: nominativ bi predstavljao samo nabrajanje, dok instrumental potiče čitatelja da intuitivno nadopuni jezičnu razinu odgovarajućim glagolom (glagolom koji naznačuje kretanje, primjerice idem ili hodam), a zatim i konceptualnu razinu odgovarajućom predodžbom.

Stih aber nichts ist eben auch dobiva konačan oblik: ali i ništa jest. Ova struktura očito predstavlja problem, no teško je odrediti je li riječ o problemu na razini deintegracije, odnosno interpretacije izvornika ili na razini integracije, odnosno uklapanja konceptualnog sadržaja u izražajne mogućnosti ciljnog jezika. Iz različitih prijevodnih varijanti zaključujemo da je riječ o problemu na objema razinama: prijevodna verzija a) predstavlja pogrešan prijevod pa bi logično bilo zaključiti da je najprije došlo do problema u interpretaciji originala, dok se ostale varijante odnose na problem integracije, to jest pronalaženja adekvatnog izraza u hrvatskom jeziku. U verziji b) promjenom glagola iz negativnog u pozitivan, prijevod postaje točan, no još uvijek nije prikladan poetskom kontekstu pjesme, dok je verzija c) sadržajno najjasnija, to jest najbliža sadržaju originala.

\section{Zaključak}


Prevođenje poezije izuzetno je zahtjevan zadatak, ne samo stoga što poezija predstavlja nerazdvojnu kombinaciju semantike, ritma i zvuka nego i zato što se ona javlja izvan konkretnog konteksta i zahtijeva da ga čitatelj/prevoditelj sam oblikuje. Ova činjenica i predstavlja faktor zbog kojeg svatko poeziju doživljava na vlastiti način i zbog kojeg je prevođenje poezije u načelu teže od prevođenja proznih djela. Ako prevođenje poezije promatramo kroz prizmu teorije konceptualne integracije, možemo uočiti važnost deintegracije izvornog sadržaja, odnosno stvaranja mentalne predodžbe kao osnove za oblikovanje pjesme u ciljnom jeziku. Izvornik nudi samo polazne točke za ovaj postupak, na prevoditelju je da ponuđeni konceptualni sadržaj nadopuni vlastitim predodžbama, pazeći pritom da ne iskače iz semantičkih okvira pjesme i teme. Analiza prijevodnih varijanti gore navedene pjesme ukazuje na korist koju početnici mogu imati od izrade prijevoda poezije kroz nekoliko etapa, čime postupno izgrađuju vlastiti svijet izvorne pjesme. Osim postupnog prevođenja od velike je koristi i suradnja s autorom koji može razjasniti određene probleme ili barem donekle ukazati u kojem smjeru treba ići interpretacija određenog stiha ili dijela pjesme.

\section{Popis literature}

Connoly, David: "Poetry Translation." Routledge Encyclopedia of Translation Studies. Ed. Mona Baker. London and New York: Routledge, 2001. 170-176. Web. 4.11.2007.

Fauconnier, Giles and Mark Turner: The Way We Think and the Mind's Hidden Complexities. Basic Books. New York 2002. Web. 20.01.2011.

France, Peter: Oxford Guide to Literature in English. Oxford UP 2000. Web. 22.01.2011.

Jakobson, Roman: "On linguistic aspects of translation." On Translation. Ed. R. Brower. Harvard: Harvard UP, 1959. 232-239. Web. 23.04.2011.

Mandelblit, Nili: Grammatical Blending: Creative and Schematic Aspects in Sentence Processing and Translation. Disseratation. UC San Diego 1997. Web. 26.09.2010.

Naaijkens, Ton: "Translating the Weltsprache of modern poetry." Übersetzung. Translation. 
Traduction. Teilband 2. Ed. Harald Kittel, Armin Paul Frank, Norbert Greiner. Berlin: Walter de Gruyter, 2007. 1669-1676. Print.

Venuti, Lawrence: The Translator's Invisibility. London and New York: Routledge, 1995. Web. 14.02.2011.

Wang Bin: "Blending Networks in Translation." Hermeneus. Num 7 - Ano (2005). 1-13. Web. 19.02.2011. 
[1] Ovdje ne tvrdimo da su u proznim djelima sadržaj i forma razdvojivi i samostalni, već da poezija predstavlja ekstreman slučaj ovakve povezanosti. Primjerice, zbog oslabljene sintakse ili njezina potpunog izostavljanja u poetskom djelu svaka riječ može imati značenje i biti neizostavan element pjesme, dok u proznom djelu ostaje više prostora za promjene.

[2] "It is widely maintained that poetry translation is a special case within literary translation and involves far greater difficulties than the translation of prose. The language of poetry will always be further removed from ordinary language than the most elaborate prose, and the poetic use of language deviates in a number of ways from ordinary use. Poetry represents writing in its most compact, condensed and heightened form, in which the language is predominantly connotational rather than denotational and in which content and form are inseparably linked." (Connolly 171) [3] „[poetry is] a constant reminder of all the things that can only be said in one language“ (citat $u$ Naaijkens 1671),

[4] „poetry by definition is untranslatable“ (Jakobson 238)

[5] „A poem could not be translated, reproduced or reassembled in the target language.." (France 92)

[6] „I continue in the belief, you know, that I don't know how to translate and that nobody does. It is an impossible but necessary process, there is no perfect way to do it, and much of it must be found for each particular poem as we go." (citat u Connolly 171)

[7] Ovdje nećemo ulaziti u modernistički pristup prevođenju koji prema T. S. Eliotu prevoditelja usmjerava na prilagodbu djela ciljnoj kulturi i vremenu. Citat nam je zanimljiv sa psihološkog stajališta jer ipak oslikava ono što prevoditelji doista čine: ugrađuju u prijevod i originalno djelo i samog sebe. Detaljnije o pristupu T. S. Eliota vidi Venuti (1995).

[8] „conceptual packets constructed as we think and talk, for purposes of local understanding and action“ (Fauconnier/Turner 40).

\section{c) (i) $9(9$}

Creative Commons Attribution-NonCommercial-NoDerivatives 4.0 International License 